\title{
Economic Viability of Solar Irrigation Pump in Jaipur, Rajasthan: An Empirical Analysis
}

\author{
Yash Gautam* and O. P. Singh \\ Department of Agricultural Economics, Institute of Agricultural Sciences, \\ BHU, Varanasi, India \\ *Corresponding author
}

\section{Keywords}

Payback period, Net present worth, Benefit Cost ratio And internal rate of return, Economic viability, Solar irrigation pump

Article Info

\section{Accepted:}

12 December 2020 Available Online: 10 January 2021

\section{A B S T R A C T}

Agriculture plays an important role in Indian economy. Agriculture sector has seen a consistent and significant growth in terms of technology and innovation which has helped India to become food exporter. However, when the focus was on improving production, the environmental aspect was forgotten. Now, government is focusing on policies and initiatives that would help in increasing agriculture production along with sustainable development. Promotion of solar irrigation pump is among one of those policies. Provision of heavy subsidies and schemes on adoption of solar pumps has increased their affordability. Because of increased affordability of solar pumps after subsidies, popularity of solar pump has increased in Rajasthan which has resulted in an increased rate of adoption. Considering the importance of solar pumps in future, this study was conducted to analyse the economic viability and costs incurred in solar pump installation. Payback period, NPV, BCR and IRR were used in the analysis.

\section{Introduction}

Since independence, India saw a significant development regarding food production and technology. Strategies of the past, focused primarily on raising agricultural production and enhancing food security. These strategies involved using better technology and varieties for increase in productivity, increased use of agro-chemicals, fertilizer, quality seed, and irrigation; incentives in the form of remunerative prices for some crops and subsidy policies for farm inputs, etc. The strategies and efforts were fruitful as the country was able to tackle severe food shortage that emerged during mid 1960s. During the last half century (1965 to 2015), since the adoption of green revolution, food production of India multiplied by 3.7 times whereas the population multiplied by 2.55 
times. The resulted in 45 per cent increase in food production per person. It made India not only self-sufficient in food at aggregate level, but also a net food exporting country (NITI AYOG, 2017). However, the strategies did not focus on raising farmers' income and welfare. Hence, the farmers' income remained low, which is evident from the prevalence of poverty among farm households. more than one fifth of rural households with selfemployment in agriculture as their principal occupation were having income less than the poverty line. This can cause serious adverse effects on the future of agriculture of the country. In this background, Prime Minister Shri Narendra Modi set the goal to double farmers' income by 2022-23. It could be done by making farmer self-reliant in various aspects. Improvement in productivity, improvement in resource use efficiency, increasing cropping intensity, diversification towards high value crops, etc can help in achieving the goal.

It should be emphasised that the policies and initiatives that aim to increase farmers income should not interfere with the environmental balance. This is because when the focus Will be on increasing farmers income then there are chances that environment health will be neglected and it has happened in the past. In green revolution, production did increase for several crops but there was depletion of water table, soil health etc. Hence, it is important that development of new technologies should go hand-in-hand with the environmental visit preservation and sustainable development.

In India, agriculture is largely rain fed and quiet vulnerable to the vagaries of the monsoon and so are the fates of millions of Indian farmers. Hence, farmers started using diesel water pumps and electric water pumps to irrigate their fields. But it increased their cost of production. With time, cost of diesel and electricity increased which further reduced the returns of farmers.
India uses more than 4 billion litres of diesel and around 85 million tons of coal per annum to support water pumping for irrigation. If one million diesel pumps were replaced with solar pumps then it would result in diesel use mitigation of approximately nine billion litres over the life cycle of solar pumps. It would save ₹ 8,400 Crores on diesel subsidy and reduce $\mathrm{CO} 2$ emission up to 25.3 million tonnes. Foreign exchange savings of USD 300 million per annum on diesel imports for replacement of one million diesel pumps translating into forex savings of USD 4.5 billions over pump life (KPMG, 2014). . Today, India relies heavily on fossil fuels to meet its energy requirements. Around 69.5 per cent of the total power is generated by thermal power plants (MoP, 2020). So it can be understood the amount of carbon dioxide that is being released in the atmosphere. In 2016, World Health Organization (WHO) released a report in which, 11 Indian cities have occupied positions in the list of top 25 polluted cities of the world (WHO, 2017). Currently India is the third largest Greenhouse gas emitter in the world after China and USA.

In order to achieve a sustainable development approach that promotes both economic and environmental objectives, the National Action Plan for Climate Change (NAPCC) was launched on 30th June 2008 in India. In subsequent efforts, Jawaharlal Nehru National Solar Mission (JNNSM) also known as National Solar Mission was launched on the 11th January, 2010. Its objective was to establish India as a global leader in solar energy. During the presentation of Union Budget 2018-19, Central Government had announced KisanUrja Suraksha Evam Utthaan Mahabhiyan (KUSUM) Scheme for farmers under which government will provide subsidy for setting up of solar power plants on their barren land. Under KUSUM scheme, government will set up 10,000 MW solar power plants on the barren lands of farmers. 
Crop production under solar irrigation system provides higher income as compare to the crop production under diesel irrigation system. It is because the irrigation charges or diesel charges in diesel irrigation system are saved in solar irrigation system. Cost of cultivation of groundnut under solar irrigation system was Rs. 74,415.29 where is the gross return obtained by farmer was Rs $1,00, .445 .41$. Hence, the net income was Rs.30,350.31 (Gautam and Singh, 2020). Similarly, the net income of farmer who produced pearlmillet under solar irrigation system was higher as compared to diesel irrigation system (Gautam and Singh, 2020). With the implementation of KUSUM scheme and other subsidies under Union Budget 2018 and state budget of Rajasthan, the popularity of solar pumps in the farming community has increased.

\section{Materials and Methods}

The study was based on primary data, collected with the help of survey schedule. Rajasthan was purposively selected because it receives the highest annual global radiation and the installation of solar irrigation pumps is maximum. Jaipur was selected purposively because number of solar irrigation pumps installed was maximum in the district. Respondents were selected with snowball sampling method. To estimate cost of installation, all the fixed and variable costs involved in the installation of solar irrigation pump was worked out starting from purchase of pumps to installation of pump along with the cost of accessories. To examine the economic viability of solar irrigation pumps, following economic criteria were employed:

\section{Payback period}

Payback period $($ years $)=$ Investment of the project /Annual net cash revenue

\section{Net Present Worth}

$N P W=\frac{P_{1}}{(1+i)^{t_{1}}}+\frac{P_{2}}{(1+i)^{t_{2}}}+\frac{P_{3}}{(1+i)^{t_{\mathrm{g}}}} \ldots . .+\frac{P_{n}}{(1+i)^{t_{n}}}-C$

Where,

$\mathrm{P}=$ Net cash flow in $\mathrm{n}^{\text {th }}$ year (years)

$\mathrm{i}=$ Discount rate

$\mathrm{t}=$ time period $($ years $)$

$\mathrm{C}=$ Initial cost of investment

\section{Internal rate of return}

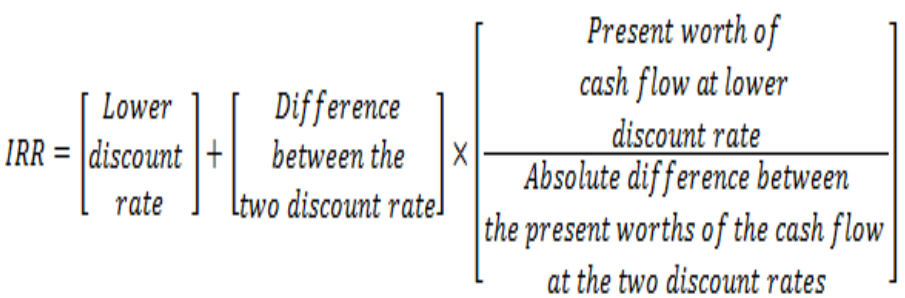

Benefit - Cost ratio

$B-C$ ratio $=\frac{\sum_{t=1}^{n} \frac{B_{t}}{(1+r)^{n}}}{\sum_{t=1}^{n} \frac{C_{t}}{(1+r)^{n}}}$

Where,

$\mathrm{B}_{\mathrm{t}}=$ Present worth of cash flow

$\mathrm{C}_{\mathrm{t}}=$ Present worth of Cost

$\mathrm{r}=$ rate of interest

$\mathrm{n}=$ number of years

\section{Results and Discussion}

\section{Cost of installation}

Average total cost of installation $5 \mathrm{HP}$ solar irrigation pump in the study area was ₹ $3,44,016$ out of which farmer's share was 30.87 per cent which amounted to Rs. $1,06,187$. Rs. $2,37,829$ was provided in the form of subsidy which contributed to the 69.13 per cent of the total cost. Total cost of solar pump included installation charges and the cost of the solar pump kit which consisted of solar panel, solar inverter, solar battery, 
junction box, DC cable, AC cable, MC4 connector, fasteners, cable tie, crimping tool, earthing kit and lighting arrestor.

\section{Cost of replacement}

Replacing an existing diesel pump with a solar irrigation pump required an amount that was equal to the cost of solar irrigation pump setup assuming that the salvage value of old diesel pump is zero. This means, when a diesel irrigation pump was replaced with a 5
HP solar irrigation pump then its replacement cost would be Rs. 3,44,016.

\section{Economic viability}

If $7 \mathrm{HP}$ diesel irrigation pump was used to irrigate 0.70 hectares of groundnut, 0.99 hectares of bajra, 1.00 hectare of wheat and 0.41 hectares of barley then the total consumption of diesel would be 41,937.89 litres per year (Gautam, 2020).

Table.1 Estimation of Net Present Value (NPV) for 5 HP solar pump

\begin{tabular}{|c|c|c|c|c|c|}
\hline $\begin{array}{c}\text { Life } \\
\text { (Years) }\end{array}$ & Cost & $\begin{array}{c}\text { Gross } \\
\text { Returns }\end{array}$ & Net Income & $\begin{array}{c}\text { Discount } \\
\text { Factor @ 0.07 }\end{array}$ & $\begin{array}{c}\text { Net Present } \\
\text { Worth @ 7\% }\end{array}$ \\
\hline $\mathbf{1}$ & 106186.79 & 41937.89 & -64248.91 & 0.935 & -60045.71 \\
\hline $\mathbf{2}$ & 0 & 41937.89 & 41937.89 & 0.873 & 36630.17 \\
\hline $\mathbf{3}$ & 0 & 41937.89 & 41937.89 & 0.816 & 34233.81 \\
\hline $\mathbf{4}$ & 0 & 41937.89 & 41937.89 & 0.763 & 31994.21 \\
\hline $\mathbf{5}$ & 3000 & 41937.89 & 38937.89 & 0.713 & 27762.17 \\
\hline $\mathbf{6}$ & 3000 & 41937.89 & 38937.89 & 0.666 & 25945.96 \\
\hline $\mathbf{7}$ & 3000 & 41937.89 & 38937.89 & 0.623 & 24248.56 \\
\hline $\mathbf{8}$ & 3000 & 41937.89 & 38937.89 & 0.582 & 22662.20 \\
\hline $\mathbf{9}$ & 3000 & 41937.89 & 38937.89 & 0.544 & 21179.63 \\
\hline $\mathbf{1 0}$ & 3000 & 41937.89 & 38937.89 & 0.508 & 19794.05 \\
\hline $\mathbf{1 1}$ & 3000 & 41937.89 & 38937.89 & 0.475 & 18499.11 \\
\hline $\mathbf{1 2}$ & 3000 & 41937.89 & 38937.89 & 0.444 & 17288.89 \\
\hline $\mathbf{1 3}$ & 3000 & 41937.89 & 38937.89 & 0.415 & 16157.84 \\
\hline $\mathbf{1 4}$ & 3000 & 41937.89 & 38937.89 & 0.388 & 15100.78 \\
\hline $\mathbf{1 5}$ & 3000 & 41937.89 & 38937.89 & 0.362 & 14112.88 \\
\hline $\mathbf{1 6}$ & 3000 & 41937.89 & 38937.89 & 0.339 & 13189.61 \\
\hline $\mathbf{1 7}$ & 3000 & 41937.89 & 38937.89 & 0.317 & 12326.74 \\
\hline $\mathbf{1 8}$ & 3000 & 41937.89 & 38937.89 & 0.296 & 11520.32 \\
\hline $\mathbf{1 9}$ & 3000 & 41937.89 & 38937.89 & 0.277 & 10766.65 \\
\hline $\mathbf{2 0}$ & 3000 & 41937.89 & 38937.89 & 0.258 & 10062.29 \\
\hline $\mathbf{2 1}$ & 3000 & 41937.89 & 38937.89 & 0.242 & 9404.01 \\
\hline $\mathbf{2 2}$ & 3000 & 41937.89 & 38937.89 & 0.226 & 8788.79 \\
\hline $\mathbf{2 3}$ & 3000 & 41937.89 & 38937.89 & 0.211 & 8213.83 \\
\hline $\mathbf{2 4}$ & 3000 & 41937.89 & 38937.89 & 0.197 & 7676.47 \\
\hline $\mathbf{2 5}$ & 3000 & 41937.89 & 38937.89 & 0.184 & 7174.27 \\
\hline & & & Total & & $\mathbf{3 6 4 6 8 7 . 5 2}$ \\
\hline & & & & & \\
\hline
\end{tabular}


Table.2 Estimation of Benefit cost ratio (B:C Ratio) for 5 HP Solar Pump

\begin{tabular}{|c|c|c|c|c|c|}
\hline $\begin{array}{c}\text { Life } \\
\text { (Years) }\end{array}$ & Cost & $\begin{array}{l}\text { Gross } \\
\text { Returns }\end{array}$ & $\begin{array}{l}\text { Discount } \\
\text { Factor @ } \\
\quad 0.07\end{array}$ & $\begin{array}{l}\text { Present worth } \\
\text { of Gross } \\
\text { return @ } 7 \%\end{array}$ & $\begin{array}{c}\text { Present } \\
\text { Worth of Cost } \\
\text { @ } 7 \%\end{array}$ \\
\hline 1 & 106186.79 & 41937.89 & 0.935 & 39194.29 & 99239.99 \\
\hline 2 & 0 & 41937.89 & 0.873 & 36630.17 & 0.00 \\
\hline 3 & 0 & 41937.89 & 0.816 & 34233.81 & 0.00 \\
\hline 4 & 0 & 41937.89 & 0.763 & 31994.21 & 0.00 \\
\hline 5 & 3000 & 41937.89 & 0.713 & 29901.13 & 2138.96 \\
\hline 6 & 3000 & 41937.89 & 0.666 & 27944.98 & 1999.03 \\
\hline 7 & 3000 & 41937.89 & 0.623 & 26116.81 & 1868.25 \\
\hline 8 & 3000 & 41937.89 & 0.582 & 24408.23 & 1746.03 \\
\hline 9 & 3000 & 41937.89 & 0.544 & 22811.43 & 1631.80 \\
\hline 10 & 3000 & 41937.89 & 0.508 & 21319.09 & 1525.05 \\
\hline 11 & 3000 & 41937.89 & 0.475 & 19924.39 & 1425.28 \\
\hline 12 & 3000 & 41937.89 & 0.444 & 18620.92 & 1332.04 \\
\hline 13 & 3000 & 41937.89 & 0.415 & 17402.73 & 1244.89 \\
\hline 14 & 3000 & 41937.89 & 0.388 & 16264.23 & 1163.45 \\
\hline 15 & 3000 & 41937.89 & 0.362 & 15200.22 & 1087.34 \\
\hline 16 & 3000 & 41937.89 & 0.339 & 14205.81 & 1016.20 \\
\hline 17 & 3000 & 41937.89 & 0.317 & 13276.46 & 949.72 \\
\hline 18 & 3000 & 41937.89 & 0.296 & 12407.91 & 887.59 \\
\hline 19 & 3000 & 41937.89 & 0.277 & 11596.17 & 829.52 \\
\hline 20 & 3000 & 41937.89 & 0.258 & 10837.55 & 775.26 \\
\hline 21 & 3000 & 41937.89 & 0.242 & 10128.55 & 724.54 \\
\hline 22 & 3000 & 41937.89 & 0.226 & 9465.93 & 677.14 \\
\hline 23 & 3000 & 41937.89 & 0.211 & 8846.67 & 632.84 \\
\hline 24 & 3000 & 41937.89 & 0.197 & 8267.91 & 591.44 \\
\hline 25 & 3000 & 41937.89 & 0.184 & 7727.02 & 552.75 \\
\hline & & & & 488726.63 & 124039.11 \\
\hline & \multicolumn{3}{|c|}{ B:C ratio } & \multicolumn{2}{|c|}{$\frac{488726.63}{124039.11}=3.94$} \\
\hline
\end{tabular}


Table.3 Estimation of Internal Rate of Return (IRR) for 5 HP Solar Pump

\begin{tabular}{|c|c|c|c|c|c|c|c|}
\hline $\begin{array}{l}\text { Life } \\
\text { (Years) }\end{array}$ & Cost & $\begin{array}{l}\text { Gross } \\
\text { Returns }\end{array}$ & $\begin{array}{l}\text { Net } \\
\text { Income }\end{array}$ & $\begin{array}{c}\text { Discoun } \\
\text { t Factor } \\
\text { @ } 0.07\end{array}$ & $\begin{array}{c}\text { Discoun } \\
\text { t Factor } \\
@ 0.3\end{array}$ & $\begin{array}{c}\text { Net } \\
\text { Present } \\
\text { Worth@ } \\
7 \%\end{array}$ & $\begin{array}{c}\text { Net } \\
\text { Present } \\
\text { Worth @ } \\
\mathbf{3 0 \%}\end{array}$ \\
\hline 1 & 106186.79 & 41937.89 & -64248.91 & 0.935 & 0.769 & -60045.71 & -49422.24 \\
\hline 2 & 0 & 41937.89 & 41937.89 & 0.873 & 0.592 & 36630.17 & 24815.32 \\
\hline 3 & 0 & 41937.89 & 41937.89 & 0.816 & 0.455 & 34233.81 & 19088.71 \\
\hline 4 & 0 & 41937.89 & 41937.89 & 0.763 & 0.350 & 31994.21 & 14683.62 \\
\hline 5 & 3000 & 41937.89 & 38937.89 & 0.713 & 0.269 & 27762.17 & 10487.10 \\
\hline 6 & 3000 & 41937.89 & 38937.89 & 0.666 & 0.207 & 25945.96 & 8067.00 \\
\hline 7 & 3000 & 41937.89 & 38937.89 & 0.623 & 0.159 & 24248.56 & 6205.39 \\
\hline 8 & 3000 & 41937.89 & 38937.89 & 0.582 & 0.123 & 22662.20 & 4773.37 \\
\hline 9 & 3000 & 41937.89 & 38937.89 & 0.544 & 0.094 & 21179.63 & 3671.83 \\
\hline 10 & 3000 & 41937.89 & 38937.89 & 0.508 & 0.073 & 19794.05 & 2824.48 \\
\hline 11 & 3000 & 41937.89 & 38937.89 & 0.475 & 0.056 & 18499.11 & 2172.68 \\
\hline 12 & 3000 & 41937.89 & 38937.89 & 0.444 & 0.043 & 17288.89 & 1671.29 \\
\hline 13 & 3000 & 41937.89 & 38937.89 & 0.415 & 0.033 & 16157.84 & 1285.61 \\
\hline 14 & 3000 & 41937.89 & 38937.89 & 0.388 & 0.025 & 15100.78 & 988.93 \\
\hline 15 & 3000 & 41937.89 & 38937.89 & 0.362 & 0.020 & 14112.88 & 760.72 \\
\hline 16 & 3000 & 41937.89 & 38937.89 & 0.339 & 0.015 & 13189.61 & 585.17 \\
\hline 17 & 3000 & 41937.89 & 38937.89 & 0.317 & 0.012 & 12326.74 & 450.13 \\
\hline 18 & 3000 & 41937.89 & 38937.89 & 0.296 & 0.009 & 11520.32 & 346.25 \\
\hline 19 & 3000 & 41937.89 & 38937.89 & 0.277 & 0.007 & 10766.65 & 266.35 \\
\hline 20 & 3000 & 41937.89 & 38937.89 & 0.258 & 0.005 & 10062.29 & 204.88 \\
\hline 21 & 3000 & 41937.89 & 38937.89 & 0.242 & 0.004 & 9404.01 & 157.60 \\
\hline 22 & 3000 & 41937.89 & 38937.89 & 0.226 & 0.003 & 8788.79 & 121.23 \\
\hline 23 & 3000 & 41937.89 & 38937.89 & 0.211 & 0.002 & 8213.83 & 93.26 \\
\hline 24 & 3000 & 41937.89 & 38937.89 & 0.197 & 0.002 & 7676.47 & 71.74 \\
\hline 25 & 3000 & 41937.89 & 38937.89 & 0.184 & 0.001 & 7174.27 & 55.18 \\
\hline & & & & & & 364687.52 & 54425.59 \\
\hline \multicolumn{8}{|c|}{$\operatorname{IRR}=(7)+(30-7)\left[\frac{1}{\mid 3}\right.$} \\
\hline
\end{tabular}


If farmer used solar irrigation pump instead of diesel irrigation pump then he would save the expenditure incurred on diesel. Hence, the incremental benefit would be equal to the total expenditure on diesel, which was, in this case Rs. 41,937.89. Economic viability of 3 HP solar pump was calculated with the help of this incremental benefit.

\section{Payback period}

Total cost of a $5 \mathrm{HP}$ solar pump was Rs. $3,44,016$. Farmer's share was Rs. 1,06,187. It was estimated that the investment made on a 5 HP solar irrigation pump would be recovered in 2.53 years.

\section{Net present Worth}

Net present worth of $5 \mathrm{HP}$ solar irrigation pump is presented in Table 1. The total cost of $5 \mathrm{HP}$ solar irrigation pump was ₹ $3,44,015.97$. Out of total cost, Government provides subsidy of ₹ $1,06,187,79$. The net cost of 5 HP solar pump for a farmer was ₹ 1,06,186.79. The economic benefit for installation of solar irrigation pump was diesel saving. Total cost of diesel saving was estimated to be 41937.89 . Life of the pump claimed by the company was 25 years. Since, the cost of repair and maintenance was covered under warranty for first 4 years, therefore, no cost was incurred in initial four years. Net present worth was found to be ₹ $3,64,687.52$ at 7 per cent discount factor (Table 1).

\section{Benefit cost ratio}

Benefit cost ratio of a $5 \mathrm{HP}$ solar pump is shown in Table 2. The total cost of 5 HP solar irrigation pump was ₹ 3,44,015.97. Out of total cost, Government provides subsidy of ₹ $2,37,829.18$. The farmers contribution of a farmer in total cost of a 5 HP solar pump was ₹ $1,06,187.79$. Gross return was estimated to be ₹ 41937.89. The economic benefit for installation of solar irrigation pump was diesel saving. Total cost of diesel saving was estimated to be 41937.89 . Farmer had to pay ₹ 3000 annually after 4th year for maintenance. Present worth of benefit and present worth of cost were ₹ 4,88,726.63 and ₹ 1,24,039.11 respectively. Benefit cost ratio was estimated to be 3.94 .

\section{Internal Rate of Return (IRR)}

Estimation of internal rate of return is shown in Table 3. The total cost of 5 HP solar irrigation pump was ₹ 3,44,015.97. Out of total cost, Government provides subsidy of ₹ $2,37,829.18$. The share of a farmer in total cost of a 5 HP solar irrigation pump was ₹ 1,06,187.79. The economic benefit for installation of solar irrigation pump was diesel saving. Total cost of diesel saving was estimated to be 41937.89 . The net present worth at lower discount rate (7 per cent) was ₹ 3,64,687.52 while at higher discount rate (30 per cent) it was ₹ $54,425.59$. Hence, the internal rate of return was 34.03 per cent.

In conclusion, findings of the study showed that $5 \mathrm{HP}$ solar irrigation pumps was cost effective especially after the huge subsidy provided by the government. Also the replacement cost was also not very high. The payback period, of solar irrigation pumps of 3 HP was 2.53 years, net present worth was ₹ $3,64,687.52$, benefit cost ratio was 3.94 and IRR was 34.03 per cent which showed that adoption of $5 \mathrm{HP}$ solar irrigation pumps was economically viable.

\section{References}

Gautam, Y. and Singh, O. P. (2020). Analysis of costs and resource productivity in pearl millet production under solar irrigation system in Jaipur, Rajasthan, Journal of Pharmacognosy and 
Phytochemistry, 9(6), 470-472

Gautam, Y. and Singh, O. P. (2020). Profitability And Resource Utilization In Groundnut Production Under Solar Irrigation System, International Journal of Current Microbiology and Applied Sciences, 9(10), 1993-1999

Gautam, Y. (2020). Economic and environmental impacts of solar irrigation pumps in Rajasthan, India [Doctoral dissertation]. Banaras Hindu University.

Klynveld Peat Marwick Goerdeler. (2014). Feasibility analysis for solar agricultural water pumps in India. KPMG Advisory Services Private Limited. https://shaktifoundation.in/wpcontent/uploads/2014/02/feasibilityanalysis-for-solar-High-Res-1.pdf

Ministry of Power. (2020). Power sector at a glance all India; 2016. Government of
India.

https://powermin.nic.in/content/powersector-glance-all-india

National Institution for Transforming India. (2017). Doubling Farmers' Income: Rationale, Strategy, Prospects and Action Plan. NITI Policy Paper No. 1/2017. National Institute for Transformation India, Government of India, New Delhi. http://niti.gov.in/writereaddata/files/doc ument_publication/ DOUBLING \%20FARMERS\%20INCOME.pdf

World Health Organization. Exposure to ambient air pollution; 2017. Retrieved from:

〈http://www.who.int/gho/phe/outdoor_a ir_pollution/exposure/en/ $/$. [Accessed on 5 August 2020].

\section{How to cite this article:}

Yash Gautam and Singh, O. P. 2021. Economic Viability of Solar Irrigation Pump in Jaipur, Rajasthan: An Empirical Analysis. Int.J.Curr.Microbiol.App.Sci. 10(01): 1780-1787. doi: https://doi.org/10.20546/ijcmas.2021.1001.208 